\title{
Exploration and Practice of Innovation and Entrepreneurship Awareness Embedded in Experimental Teaching of Economic Management Major Undergraduates: A Case Study from China
}

\author{
Yifan Zuo ${ }^{1,2}$, Dan Yao ${ }^{1} \&$ Mu Zhang ${ }^{1}$ \\ ${ }^{1}$ Laboratory on GIS \& tourism IT, Jinan University Shenzhen Campus, Shenzhen, China \\ ${ }^{2}$ School of Management, Jinan University, Guangzhou, China \\ Correspondence: $\mathrm{Mu}$ Zhang, Shenzhen Tourism College, Jinan University, Shenzhen, Guangdong Province, \\ 518053 China. Tel: 86-138-2438-8695. E-mail: zhangmu@163.com
}

$\begin{aligned} & \text { Received: May 19, } 2020 \quad \text { Accepted: June 15, } 2020 \quad \text { Online Published: June 23, } 2020 \\ & \text { doi:10.5539/hes.v10n3p53 }\end{aligned}$ URL: https://doi.org/10.5539/hes.v10n3p53

\begin{abstract}
China has proposed a new strategy driven by innovation, placing scientific and technological innovation at the core of the country's overall development, and seeing it as a strategic support for improving social productivity and overall national strength. This puts forward new requirements for the construction of high-level universities and the cultivation of high-level talents. Undergraduates are currently the largest reserve talents in colleges and universities. To meet the needs of the new situation, it is the right time to train undergraduates who are innovative and entrepreneurial. Deepening the reform of innovation and entrepreneurship education in colleges and universities is a practical need for undergraduates to realize the Chinese dream. Facing the urgency of society's need for innovative and entrepreneurial talents, there is an urgent need to embed innovative and entrepreneurial elements in the undergraduate training process. This requires further deepening reforms in the content, form and structure of education to meet the needs of undergraduates for innovation and entrepreneurship.
\end{abstract}

Keywords: undergraduate students, experimental teaching, innovation and entrepreneurship, China

\section{Introduction}

In 2015, the Chinese government issued an overall plan to promote the construction of world-class universities and disciplines. This is the latest form of China's development of key universities and key discipline policies. The overall requirements of the new policy are to take Chinese characteristics and world-class as the core, establish people, and support innovation-driven development strategies and serve the economy and society as the guide to accelerate the construction of a number of world-class universities and first-class disciplines. In the policy, many references to innovation and entrepreneurship are mentioned. In terms of talent training, it is proposed to strengthen innovation and entrepreneurship education, vigorously promote personalized training, and comprehensively improve students' comprehensive quality, international vision, scientific spirit, entrepreneurial awareness and creative ability. Reasonably increase the proportion of college graduates' entrepreneurship, and guide college graduates to actively participate in mass entrepreneurship and innovation. The policies of mass entrepreneurship and innovation are of special significance to China today. The innovation awareness and entrepreneurial skills of undergraduates have become a topic of common concern in Chinese universities. Because first-class undergraduate education is an important foundation and basic feature for building a first-class university, many colleges and universities incorporate innovative and entrepreneurial talent training mechanisms into the concept of undergraduate scholarship. Undergraduates are currently the largest reserve talents in colleges and universities. To meet the needs of the new situation, it is the right time to train undergraduates with a sense of innovation and entrepreneurship.

The construction of Chinese universities is inseparable from the support of laboratories, and the first-class undergraduate education is also inseparable from first-class experimental teaching. The construction plan of the National Teaching Demonstration Center in China, which began in 2007, has enabled the rapid development of experimental teaching in colleges and universities, and the rapid improvement of the hardware conditions and scientific research level of the laboratory. How to give full play to the advantages of undergraduate experimental 
teaching and embed innovation and entrepreneurship in the teaching process, this is a problem that experimental teaching staff are thinking deeply.

Deepening the reform of innovation and entrepreneurship education in colleges and universities is the current needs of China's national economy and social development. Facing the urgency of the society's need for innovative and entrepreneurial talents, undergraduates need to embed the elements of innovation and entrepreneurship in the process of training. This requires further exploration and practice in education content, structure, form, etc (Dong, Wang, Han, \& Zhang, 2019). This article explores the key issues of embedding innovation and entrepreneurship in undergraduates' experimental teaching from three aspects: experimental teaching concept and reform ideas, experimental teaching system and content, experimental teaching methods and means, taking the undergraduate experimental teaching of Chinese economics and management as an example And practice. The construction ideas and measures are proposed to provide exemplary cases for the training units of economic management undergraduates, and to provide experience and reference for the design of experimental teaching and the construction of experimental teaching demonstration centers in other world universities.

\section{Experimental Teaching Ideas and Reform Ideas}

\subsection{Teaching Philosophy}

Experimental teaching is an important part of the applied, communicative, open talent training system. The experimental teaching concept reflects the scientific development concept, with students as the center, with innovative talent training as the core of the work, and the implementation of open experimental teaching To promote the comprehensive and coordinated development of students' knowledge, abilities, thinking and qualities (Gorgul \& Gorgul, 2012).

In the course of development, the disciplines of liberal arts and management closely combined with the practical needs of the development of social sciences, tracked and utilized modern information technology, and continuously deepened the teaching reform of liberal arts and management majors. In particular, experimental teaching emphasizes organically combining theoretical teaching with practical teaching, combining in-class teaching with extra-curricular practice, combining in-school training with industry practice, forming a multi-dimensional interactive talent training mechanism, and building a bridge for students' innovation and entrepreneurship (Lopes \& Cunha, 2017). By constructing an experiment and practice base that integrates theory and practical teaching, and in-class and extra-curricular teaching, the experimental teaching system is improved to enlighten students' innovative thinking, develop innovative potential, cultivate innovative ability, and strengthen comprehensive ability training. In order to improve the students' ability to use the professional knowledge learned and modern scientific and technological means to solve various practical problems in the industry and practical operation ability (Choe, Park, \& Yoo, 2014).

\subsection{Orientation and Planning of Experimental Teaching}

In the liberal arts internship experimental teaching system, there are also many basic internships and experimental activities. It is one of the basic teaching forms for fostering experimental skills, scientific thinking and methods, innovative awareness and ability in social science education in colleges and universities, and comprehensively promoting quality education One (Ming-chao \& Jing, 2012). To achieve the above teaching goals, we must provide students with a new and scientific experimental teaching system. The focus is on the integrated design and reform of the internship experimental course system, teaching content, teaching mode, teaching methods and means, teaching management, etc., and proposes an integrated, multi-level, open innovative experimental teaching system Formulated experimental courses and teaching contents for different undergraduates and graduate students at different levels, which breaks the traditional experimental teaching system with too many experimental courses and cross-repetition of some contents, and provides comprehensive sustainable development and healthy growth for students Foundation.

To this end, centering on experimental teaching, we always adhere to the cultivation of innovative ability, give full play to the important role of experimental teaching in the process of talent training, and constantly improve and deepen the multi-dimensional interaction and overall improvement of the practical experimental teaching system to maximize and strengthen students. The hands-on ability and innovative thinking are based on the laboratory situation shaping and the entry point to enhance the innovation and entrepreneurship awareness of undergraduates in tourism management.

This positioning will follow the principle of high starting point, new ideas, distinctive features, and heavy utility. A high starting point is to equip the laboratory with new and advanced technology to avoid low-level repeated 
construction; the new idea is to stand on the cultivation of thick foundation, strong theory, heavy application, strong adaptability and innovative entrepreneurial ability, pioneering The height of spiritual talents, build a comprehensive, design and innovative experimental environment, gradually reduce the verification and unity of experiments, increase comprehensive, innovative and design experiments, and form the concept of coordination of theoretical teaching and experimental teaching. And atmosphere, and fundamentally change the traditional concept of experimental teaching relying on theoretical teaching; the characteristic is to highlight the school running characteristics and professional characteristics, professional laboratories must serve to train competitive talents, and serve to increase the popularity of schools and professions; Heavy utility is to build a laboratory that can maximize its effectiveness. All experimental equipment and software systems should be able to form the experimental teaching ability at the fastest speed, and can provide students with open experimental conditions, strive to improve the input-output ratio, and strive to The conversion rate of scientific research achievements has been improved. To achieve this positioning, the following strategic countermeasures are proposed:

a) In line with the principle of strengthening the foundation, optimizing the structure, promoting the construction of disciplines, and cultivating innovative talents, we will further improve the construction of existing laboratories, and increase the scope of experiments from the field of skill operations for undergraduates to academic research, and promote Organic combination of research.

b) Adapt to the new demands of the industry for professional practice teaching in the information age, constantly update the experimental equipment and related software, add new experimental projects, and better integrate with the industry. Further explore the management model and incentive mechanism for integrating resources, ensuring quality, and promoting output, and strengthen the linkage construction between experimental teaching centers.

c) Strengthen the construction of experimental teaching materials, and compile and publish experimental textbooks that meet the requirements of current professional information technology development under the guidance of guarantee foundation, strengthen application.

d) Continue to expand cooperation with the industry, network and software industry and related companies, borrow industry experience and resources to make laboratory construction advance with the times; at the same time provide training, consulting, survey and research services for the development of the industry (Ahmad, Abu Bakar, \& Ahmad, 2018).

\subsection{The Idea and Plan of Experimental Teaching Reform}

In the experimental teaching process in recent years, I deeply felt that there are three major problems in the current teaching model adopted by the undergraduate majors: (a) Failure to properly resolve the contradiction between knowledge transfer and ability and quality training, one-sided emphasis on the transfer of knowledge Ignoring the integration of knowledge and the construction of knowledge meaning, ignoring the internalization of knowledge into the improvement of students' abilities and qualities; (b) failure to properly handle the contradiction between theory and practice, one-sided emphasis on theoretical teaching, ignoring the application of experimental teaching and theory; (c) Failure to properly handle the contradiction between teaching and learning. The organization of teaching activities is centered on teaching, not on learning, and ignores the autonomy, initiative and creativity of students in learning. In fact, in the liberal arts management major, the traditional theory plus case teaching method has shown its weaknesses. Because there is no practical operation and simulation practice, students often feel that the theoretical knowledge of books and the actual business operation are far from each other. Cultivation of innovation and entrepreneurship (Katz-Buonincontro, Perignat, $\&$ Hass, 2020).

Therefore, the goal of experimental teaching is to narrow or even eliminate this gap, to closely connect theory with practice, to enable students to have a deeper grasp of theoretical knowledge and apply it to practice, while cultivating students' sense of innovation and entrepreneurship. In order to achieve this goal, continuous improvement and improvement in teacher training, experimental teaching environment, experimental teaching software, and experimental teaching courses are required. To this end, the reform idea of experimental teaching is put forward, with the goal of cultivating and improving students' innovative ability and pioneering spirit, in order to meet the needs of talent training at different levels, according to the characteristics of each major in economic management disciplines, construct a The comprehensive experimental teaching system of liberal arts from the undergraduates to the postgraduates is divided into different levels, modularity, combination of points and planes. The experimental content is from shallow to deep, from simple to complex, from passive operation to active design or simulation to innovative comprehensive use, gradually deepening the depth, breadth and comprehensiveness of the experimental teaching content, in line with the laws of cognition and teaching, and 
achieved good results Teaching effect.

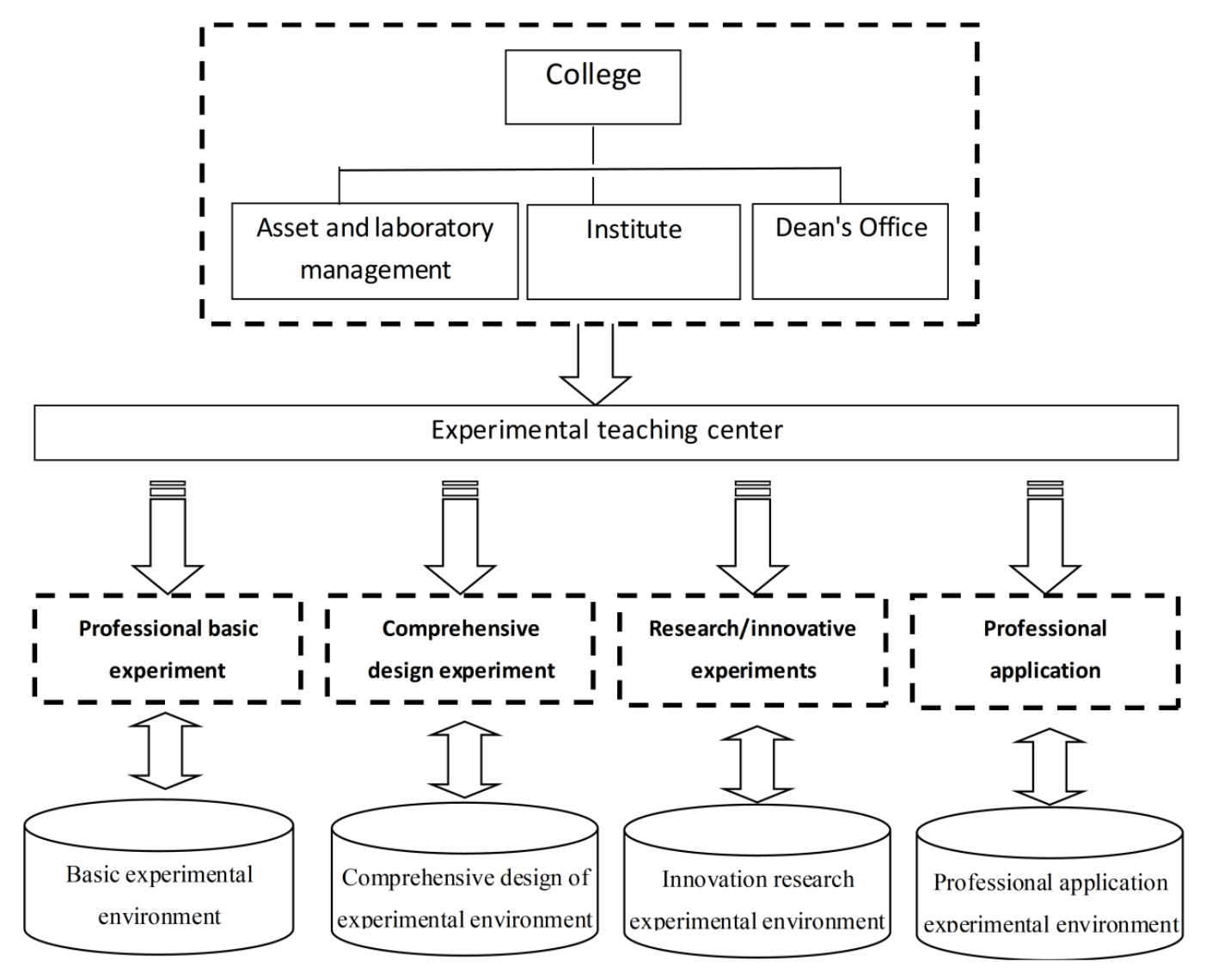

Figure 1. Construct Experimental Teaching Center System

The experimental teaching center tracks the development trend of modern information technology and creates a series of experimental teaching technology platforms synchronized with information technology to provide technical equipment and technical support for students' practical operations.

\subsubsection{Established an Effective Internship Experiment Teaching Model}

Autonomous learning is under the guidance of teachers, students use the existing experimental teaching conditions to actively study and carry out research. It requires students to have a conscious awareness and response to the questions of why, what, and how to learn, and cultivate the ability of autonomous learning. For example, tourism resource courses include tourism resource survey, resource development and planning, landscape design and evaluation, etc., all can use the results of field surveys and industry development experience as a reference for self-study design, making online courses or multimedia courseware for students Provide a large number of learning resources, create an online learning discussion area, and use the learning environment such as context, collaboration, and conversation to give full play to the initiative, enthusiasm and initiative of students, and finally achieve the purpose of enabling students to effectively build the current knowledge. Another example is the marketing course, by organizing students to carry out scenic survey activities, students design questionnaires, group surveys, and analyze statistics through SPSS or SAS software, so that students not only master the basic methods of questionnaire statistics, but also operate and operate scenic spots. The situation has a more intuitive understanding.

\subsubsection{Established an Open Practice Teaching Base and Platform}

Practicing the teaching concept of open school, while strengthening its own construction, it actively cooperates with various industries to jointly build an internship base as an organic extension of the experimental teaching center. The experimental teaching center and the practice base outside the school form a complementary practice experimental teaching platform, which lays a solid foundation for comprehensively improving the quality of practical teaching. 
2.3.3 Establish the Connection Mechanism between the Experimental Teaching Center and the Activities Inside and Outside the School

Combined with campus cultural activities, the center supports students to combine professional characteristics and plan and organize campus cultural activities related to professional practice. For example, cultural activities such as cultural festivals can increase knowledge. There are also campus photography contests, campus public welfare advertising contests, self-run electronic magazine contests, etc .combined with technological innovation activities, actively organize students to use the experimental teaching center as a platform to participate in the Challenge Cup, undergraduate innovation engineering projects or other research Projects; combined with the practice of self-employment, students are encouraged to set up self-employment projects with the help of experimental teaching centers, in order to improve students' self-employment ability and market competitiveness.

\subsubsection{Constructed A Management Support System for Teaching and Learning}

For a long time, many colleges and universities have actively deepened the reform of experimental teaching, explored the construction of a new experimental teaching system based on students, and cultivated practical and innovative abilities as the core, established an advanced, efficient and open laboratory management system and operating mechanism, and built a structure Reasonable, high-quality experimental teaching team combining theoretical teaching and practical teaching, constructing an experimental teaching environment with advanced instruments and equipment and rich network sharing resources to comprehensively improve the quality of experimental teaching. The development planning of multiple schools has clarified the construction and development goals of experimental teaching, strengthened the construction and management of experimental design, and improved the experimental teaching conditions. Focusing on the needs of research teaching and innovation, promote the sharing of professional laboratories and scientific research laboratories, realize the sharing of instruments and equipment, improve the utilization rate and use efficiency of laboratories and equipment; focus on the construction of experimental teaching centers, promote the construction of laboratories, Integrate the original information platform and resources to build a large experimental teaching platform for the whole hospital; strengthen the construction of experimental technical teams and promote the scientific, standardized and modernized laboratory management. While investing heavily in the construction of laboratory hardware environment, the laboratory The construction of software environment (including the reform of experimental teaching, management system and system, the construction of experimental team, the construction of experimental teaching materials, the improvement of laboratory investment and use efficiency) has also been valued by most universities.

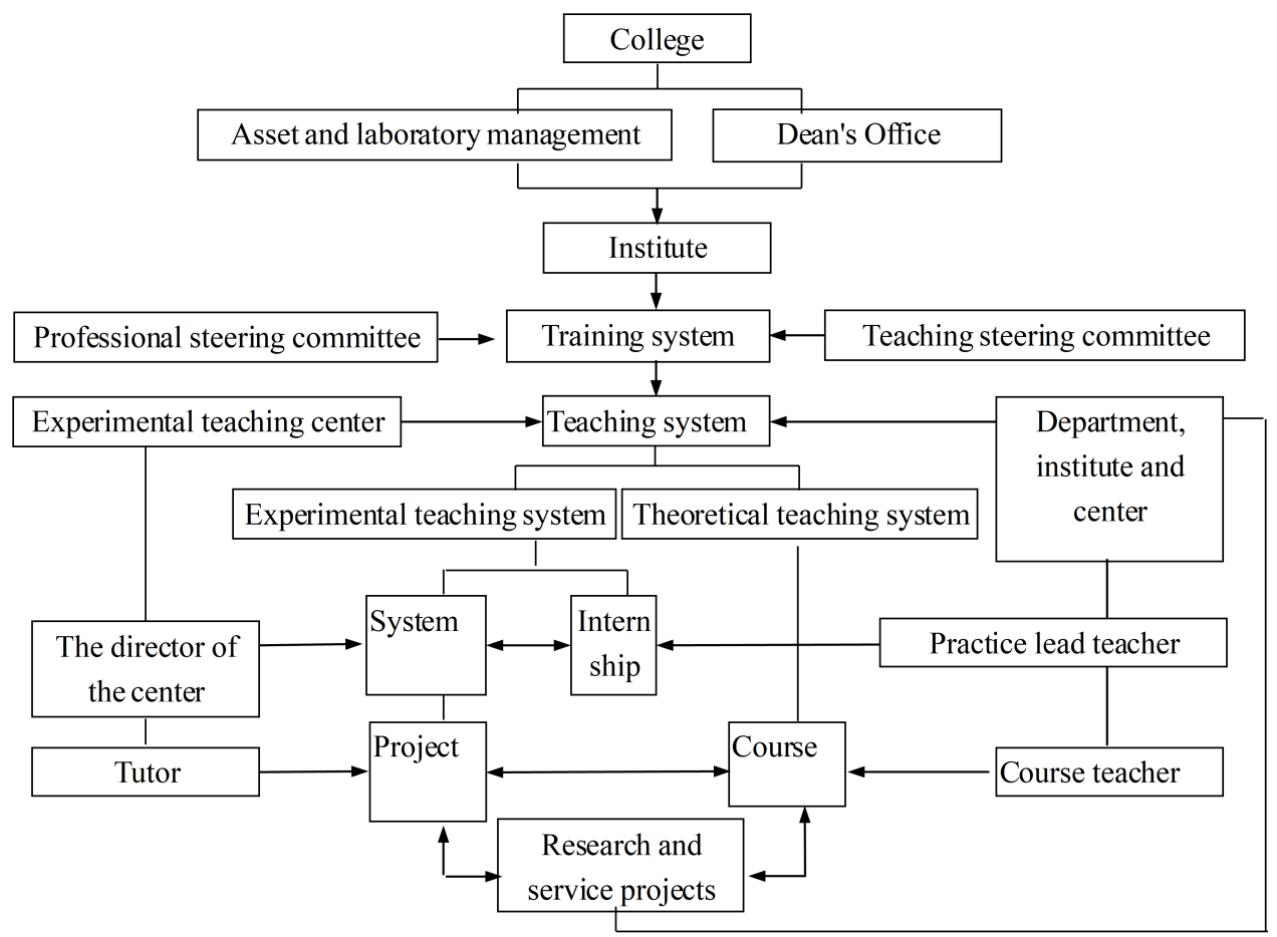

Figure 2. Experimental teaching center management system 


\section{Experimental Teaching System and Content}

\subsection{Modular Experimental Teaching System}

As different majors have different subject backgrounds and different working methods, the center divides the experimental teaching courses of all majors into four different modules to enhance the pertinence of the professional experimental teaching, taking the tourism management major as an example, as shown in table 1.

Table 1. List of experimental courses corresponding to experimental teaching systems of different majors

\begin{tabular}{|c|c|}
\hline $\begin{array}{l}\text { Experimental teaching } \\
\text { system }\end{array}$ & Corresponding experimental courses \\
\hline $\begin{array}{l}\text { Tourism management } \\
\text { experimental teaching system }\end{array}$ & $\begin{array}{l}\text { Spatial database design, overlay analysis, electronic map, 3d scenic spot design, } \\
\text { scenic spot information design, } 2 \mathrm{~d} \text { and } 3 \mathrm{~d} \text { animation, CAD }\end{array}$ \\
\hline $\begin{array}{l}\text { Electronic commerce } \\
\text { experiment teaching system }\end{array}$ & $\begin{array}{l}\text { Database design, } C \text { language, computer graphics, web design and production, } \\
\text { network security testing, logistics simulation, database engine }\end{array}$ \\
\hline $\begin{array}{l}\text { Business English } \\
\text { experimental teaching system }\end{array}$ & $\begin{array}{l}\text { Independent training of business English application ability (multimedia), } \\
\text { business English interpretation simulation practice (multimedia), business } \\
\text { English simultaneous interpretation simulation practice }\end{array}$ \\
\hline $\begin{array}{l}\text { Scientific research } \\
\text { experiment teaching system }\end{array}$ & $\begin{array}{l}\text { Market research and analysis, marketing and network marketing research } \\
\text { methods }\end{array}$ \\
\hline
\end{tabular}

\subsection{Hierarchical Experimental Teaching System}

After years of practice and exploration, the experimental teaching system of basic experiment, comprehensive experiment, design experiment and innovative experiment has been gradually formed.

The purpose of the basic experiment is to train the basic skills and consolidate the theoretical knowledge in the classroom teaching according to the most basic requirements that the professional training goals should meet; the comprehensive experiment focuses on cultivating the students' comprehensive ability to use the basic experimental skills according to the characteristics of the relevant professional To lay the foundation for the development of innovative and design experiments; innovative and design experiments as an improved level of experiment (practice) project, focusing on cultivating students' sense of innovation and the ability to apply the professional knowledge learned for scientific research.

Basic experiments take individuals as experimental units and are completed within the prescribed time; comprehensive experiments take groups as experimental units and can be completed in the laboratory opening hours outside of class hours; research innovative experiments take groups as students 'units Completed in spare time, it can be combined with the work of graduation thesis. Innovative and design experiments are generally completed by students independently under the guidance of teachers. Basic experimental projects remain stable. Comprehensive experimental projects are constantly updated with the development of disciplines on a relatively stable basis. Innovative and design experiments should pay particular attention to selecting some projects with strong practicality and close connection with practical applications, so the update cycle Faster. The various parts of the experimental teaching system are interlocking and in-depth, which greatly strengthens the cultivation of innovative practical ability (Ran, 2012). Taking the tourism management major as an example, see Table 2 for details. 
Table 2. Various experimental courses

\begin{tabular}{|c|c|}
\hline Type & The experimental course \\
\hline Basic experiment & $\begin{array}{l}\text { Spatial data collection and editing, Electronic map design and implementation, Bar code } \\
\text { technology application, Hotel agents business operations, Travel agency background sales } \\
\text { operations, Golf mechanism experiments, Third-party digital authentication, Electronic } \\
\text { payment, Internet and network tools use }\end{array}$ \\
\hline $\begin{array}{l}\text { Comprehensive } \\
\text { experiment }\end{array}$ & $\begin{array}{l}\text { Spatial analysis, Call center, ticketing and check-in system, Logistics, information } \\
\text { technology, The third party logistics management, Hotel consumption behavior simulation, } \\
\text { Travel agency contract management, The use of the principle and the Snort intrusion } \\
\text { detection, Customer relationship management system (CRM), Enterprise resource planning } \\
\text { (ERP) system simulation, B2C e-commerce simulation, C2C network marketing actual } \\
\text { combat, Online market research }\end{array}$ \\
\hline $\begin{array}{l}\text { Design } \\
\text { experiment }\end{array}$ & $\begin{array}{l}\text { Graphic database design, scenic site design, landscape design, Travel agency line design and } \\
\text { team management, Business website establishment and maintenance, Network advertising } \\
\text { planning, Production and release }\end{array}$ \\
\hline $\begin{array}{l}\text { Innovative } \\
\text { experiment }\end{array}$ & $\begin{array}{l}\text { Web GIS, Tourism GIS framework design, ASP comprehensive programming, } \\
\text { Multi-dimensional data organization and analysis (OLAP), Network marketing methods and } \\
\text { means of comprehensive application, Data warehouse construction }\end{array}$ \\
\hline
\end{tabular}

\subsection{Three-dimensional Experimental Teaching System}

Since the experimental teaching of various majors involves comprehensive, designing and innovative experiments, it is necessary not only to get experimental training in class, but also to get further practical exercise outside class. Therefore, it is necessary to closely integrate experimental teaching with campus cultural activities, technological innovation activities, scientific research activities and open experimental projects, thus forming a three-dimensional experimental teaching system.

\subsection{Seamless Connection of the Practice Teaching System inside and Outside the School}

In order to further strengthen the practical ability and innovation ability of students majoring in literature, economics and management, organically integrate the professional internship experimental teaching in the school with the business training of the outreach practice base of the school, effectively extend or expand the connotation and extension of the experimental teaching, and deepen the professional experimental teaching. Which builds a seamless connection between in- and out-of-school practice teaching.

\section{Experimental Teaching Methods and Means}

\subsection{Experimental Teaching Methods}

Case-based teaching, according to the academic background and teaching characteristics of different majors, different case teaching modes can be selected: (a) unexpected cases, for example, reflecting the unexpected and reasonable incidents that occur during the operation of the enterprise. (b)Thematic case, a typical example of teaching activities around a certain theme. (c)Integrated case, this is a typical example of using a lesson or a section of teaching material for teaching. (d)Project research-style case, this is a typical example of students' independent research according to the subject under the guidance of teachers. Through such teaching, students follow teachers to analyze and study cases, and through analysis and discussion, guide students to enter the real situation of business operation and management, and improve the ability to analyze and solve problems(Dorta-Afonso,2019;Olokundun et al.,2018).

Project-style teaching, guide students to participate in a real enterprise practical project operation, sum up experience and lessons in actual combat, and deepen the understanding of theoretical knowledge. For example, arrange students to use relevant data collected by themselves to design and produce a resource survey and evaluation analysis report.

Research teaching, guiding students to carry out scientific research on various issues in industry practice and development. Students can use the experimental teaching center to independently conduct scientific research or technological innovation and participate in various competitions such as the "Challenge Cup". For example, the courseware design of experimental courses for business English majors is based on neuroscience theory, which is in accordance with the cognitive law of the brain 's foreign language acquisition; the experimental platform is used to track and dynamically evaluate students 'learning behavior, quantify the quality of students' learning behavior The process provides timely guidance; at the same time, it can also provide teachers with personalized 
guidance for students to ensure the quality of the entire learning process.

Interactive teaching has formed a multi-level interaction: First, the interaction between teachers and students, teachers provide resources, design tasks, students learn independently, and create independently. Establish interaction through extracurricular research activities and communicate through the center's network information platform. The second is student-student interaction, through the design of team experiment projects, to promote communication, learning and discussion among students, and cultivate their team spirit and sense of cooperation. The third is the interaction between the experiment center and the off-campus practice base. Through interaction with the enterprise and other practice bases, students are led to enter the industry and realize the integration of experimental teaching and social practice (Teo, 2019).

\subsection{Experimental Teaching Methods}

\subsubsection{Multimedia Teaching}

In teaching, teachers give full play to the multimedia presentation function, use multimedia courseware to provide students with a lot of resources, demonstrate various cases, and make the experimental teaching more intuitive and vivid. Use field internship opportunities, collect more data and background materials that are similar to the major, and closely integrate with the current teaching experiment platform to implement teaching, so that students can understand the operation of the enterprise in virtual scenarios (Zhang \& Chen, 2012). The development of information technology has caused earth-shaking changes in the experimental teaching environment of liberal arts economic management majors. In recent years, experimental teaching has also achieved a leap from the traditional manual operation and sand table simulation to the advanced computer simulation and network management CAI environment by equipping advanced computers and network equipment (Wanliang \& Dan, 2011). Today, 80\% of the experimental projects in the Experimental Teaching Center are simulated or operated by computers, and $60 \%$ of the projects are conducted in the Internet or Intranet environment. Traditional technical experiments have also dropped the wall charts, teachers 'hands, and face-to-face tutoring methods. One-to-one tutoring through computer network, realized by electronic slide, video and electronic classroom system (Cui \& Wang, 2017). The advanced technology has caused a huge change in the content, depth and breadth of the experimental courses from quantity to quality, and the experimental teaching effect and quality have been significantly improved. Make full use of the advantages of modern educational technology, make online courses or multimedia courseware, provide students with a lot of resources, and create online learning discussion areas (Dias Pereira et al., 2016).

\subsubsection{Hierarchical Teaching}

Carry out different experimental teaching according to different experimental levels.

\subsubsection{Basic Experiment}

This type of experiment is mainly for low-level students or non-major students, including three levels. The first level, cognitive or demonstrative experiments. Used for students' comprehensive understanding of the professional knowledge involved in the experiment; the second level, confirmatory or simulation experiments. Verify the important conclusions in theoretical teaching through experiments, and use the experimental teaching environment to reproduce and observe the operation process of business management activities, such as the "tourism management information system" to let students fully understand the entire process of information transformation of tourism enterprises; third Level, application and production experiments. According to the requirements of theoretical teaching, complete experimental operations and production and design, such as the construction and maintenance of business websites, so that students understand the whole process of building a business website.

\subsubsection{Comprehensive Experiments Reflecting Professional Characteristics}

Through this kind of experiment project mainly based on simulation experiments, students can be simulated to participate in management activities, so that they feel the atmosphere that is almost consistent with real business activities. In the past two years, international trade, trade economy, marketing, e-commerce and other majors have arranged such experiments in professional training courses.

\subsubsection{Innovative and Design Experiments}

As the advanced level of experimental teaching, this is an experiment to cultivate students' initiative and consciousness, which is mainly carried out among senior students. Experimental projects generally come from teachers' scientific research topics or students develop and research in the laboratory according to their own scientific research ideas. Such as the planning of e-commerce projects, logistics management projects, the 
production and preview of marketing programs, etc., where the combination of college student entrepreneurship project competition is an important part of such experiments.

\subsection{Experimental Assessment Method}

In order to fully embody the concept of modern education evaluation and measurement, different assessment methods need to be formulated according to different experimental courses. Considering the experimental teaching content of experimental projects at different levels, taking into account the experimental learning process and experimental learning results, a corresponding experimental teaching evaluation system was formulated (LaVelle, Lovato, \& Stephenson, 2020).

It has set up a diversified assessment method that combines practical ability assessment, individual work assessment, group work assessment, and theoretical knowledge written examination assessment. We will strive to combine the assessment of theoretical knowledge and the ability to use theoretical knowledge to solve practical problems in a comprehensive manner. The assessment of individual and the assessment of learning groups will be combined. The assessment of learning results and the assessment of learning processes will be combined to ensure the scientificity and accuracy of assessment.

The specific assessment of experimental teaching adopts the method of combining the itinerary and the finality, that is, combining the characteristics of the course and the teaching requirements, establishing a comprehensive assessment system based on basic theory and basic skills, focusing on comprehensive application ability, and taking learning attitude as reference, Pay attention to the diversification of assessment methods and the standardization of assessment indicators, in order to maintain the objective and fairness of the examination of students' academic performance and teacher's teaching effect. Basic experiments and comprehensive experiments with professional characteristics mainly evaluate and determine the results from the three aspects of attendance, examination of the experimental process and experimental reports. Innovative and design experiments are generally individually tested and scored, and the final results are determined after the application of the excellent experimental group by on-site display, questioning, and simple answering by students (Naumann, Rieser, Musow, Hochweber, \& Hartig, 2019).

\section{Conclusion}

Nowadays, the innovation awareness and entrepreneurial skills of undergraduates have become the focus of attention in college education. Innovative consciousness usually requires a collection of knowledge in multiple disciplines to make it possible for undergraduates to comprehensively think about problems and propose solutions to problems, but students are usually reluctant to spend too long a period of time to complete the education before obtaining Inspiration for innovation and entrepreneurship. Therefore, in each teaching cycle, such as one semester and one school year, it is a worthwhile idea to develop open and innovative experimental projects to get inspiration from it. Classroom teaching usually imparts systematic knowledge and skills, can guide undergraduates to gradually master a specialized and regular knowledge system, and promote undergraduates to learn scientific thinking and tend to mature. However, the awareness of innovation and entrepreneurship can obviously not be cultivated in a regular manner. Undergraduates always want to think of innovative and entrepreneurial ideas as soon as possible, so as to enter the role as soon as possible. This has created a paradox. It is difficult for traditional classroom teaching to meet the needs of undergraduates in innovation and entrepreneurship immediately. In this situation, in the traditional professional teaching system, an open learning environment is integrated, or for undergraduates. It is indispensable for us to create educational activities suitable for fostering awareness of innovation and entrepreneurship. From the years of teaching practice experience, the experimental teaching project can enlighten the innovative and entrepreneurial ideas of undergraduates in a short period of time. Classroom theoretical teaching carries the task of systematic knowledge transfer, and experimental teaching is the specific application of restoring theory to guide practice, and has strengthened the practice and hands-on ability of liberal arts and economics undergraduates. The coordination between theory and experimental teaching is a key link to inspire the innovation and entrepreneurship awareness of liberal arts undergraduates in economics and management.

\section{Acknowledgement}

This work was supported by the Degree and Graduate Education Reform Key Projects of Guangdong Province, and the title is Exploration and Practice of Postgraduate Cultivation in Incorporating Innovation and Entrepreneurship Consciousness. Also, it was supported by the project of China Higher Education Association Thirteenth Five-Year Plan for Scientific Research in Higher Education (Grant number: 2018SYSZD08). 


\section{References}

Ahmad, S. Z., Abu Bakar, A. R., \& Ahmad, N. (2018). An evaluation of teaching methods of entrepreneurship in hospitality and tourism programs. The International Journal of Management Education, 16(1), 14-25. https://doi.org/10.1016/j.ijme.2017.11.002

Choe, K., Park, S., \& Yoo, S. Y. (2014). Effects of constructivist teaching methods on bioethics education for nursing students: A quasi-experimental study. Nurse Education Today, 34(5), 848-853. https://doi.org/10.1016/j.nedt.2013.09.012

Cui, Z., \& Wang, J. (2017). Research of An Intelligent Experimental Teaching Platform Based on Internet. Procedia Computer Science, 107, 75-79. https://doi.org/10.1016/j.procs.2017.03.059

Dias Pereira, L., Dias Carrilho, J., Brito, N. S., Rocheta Gomes, M., Mateus, M., Chenari, B., ... Gameiro Da Silva, M. (2016). Teaching and researching the indoor environment: From traditional experimental techniques towards web-enabled practices. Sustainable Cities and Society, 26, 543-554. https://doi.org/10.1016/j.scs.2016.03.008

Dong, Q. W., Wang, S. M., Han, F. J., \& Zhang, R. D. (2019). Innovative Research and Practice of Teachers' Teaching Quality Evaluation under the Guidance of 'Innovation and Entrepreneurship'. Procedia Computer Science, 154, 770-776. https://doi.org/10.1016/j.procs.2019.06.123

Dorta-Afonso, D. (2019). Teaching organizational behavior in the bachelor of tourism through the case study method. Journal of Hospitality, Leisure, Sport \& Tourism Education, 25, 100204. https://doi.org/10.1016/j.jhlste.2019.100204

Gorgul, E., \& Gorgul, E. (2012). Teaching creativity: Developing Experimental Design Studio Curricula for Pre-College and Graduate Level Students in China. Procedia - Social and Behavioral Sciences, 51, 714-720. https://doi.org/10.1016/j.sbspro.2012.08.230

Katz-Buonincontro, J., Perignat, E., \& Hass, R. W. (2020). Conflicted epistemic beliefs about teaching for creativity. Thinking Skills and Creativity, 36, 100651. https://doi.org/10.1016/j.tsc.2020.100651

LaVelle, J. M., Lovato, C., \& Stephenson, C. L. (2020). Pedagogical considerations for the teaching of evaluation. Evaluation and Program Planning, 79, 101786. https://doi.org/10.1016/j.evalprogplan.2020.101786

Lopes, J. B., \& Cunha, A. E. (2017). Self-directed professional development to improve effective teaching: Key points for a model. Teaching and Teacher Education, 68, 262-274. https://doi.org/10.1016/j.tate.2017.09.009

Ming-chao, L., \& Jing, L. (2012). Goal-Oriented Method and Practice in Experimental Teaching. IERI Procedia, 2, 480-484. https://doi.org/10.1016/j.ieri.2012.06.120

Naumann, A., Rieser, S., Musow, S., Hochweber, J., \& Hartig, J. (2019). Sensitivity of test items to teaching quality. Learning and Instruction, 60, 41-53. https://doi.org/10.1016/j.learninstruc.2018.11.002

Olokundun, M., Moses, C. L., Iyiola, O., Ibidunni, S., Ogbari, M., Peter, F., ... Borishade, T. (2018). The effect of non traditional teaching methods in entrepreneurship education on students entrepreneurial interest and business startups: A data article. Data in Brief, 19, 16-20. https://doi.org/10.1016/j.dib.2018.04.142

Ran, Z. (2012). Exploration on the Key Issues of Practical Teaching Reform of Computer Network. Energy Procedia, 17, 1914-1919. https://doi.org/10.1016/j.egypro.2012.02.332

Teo, P. (2019). Teaching for the 21st century: A case for dialogic pedagogy. Learning, Culture and Social Interaction, 21, 170-178. https://doi.org/10.1016/j.lcsi.2019.03.009

Wanliang, H., \& Dan, L. (2011). Experimental Research on the Multimedia CAI Courseware in the University Tennis Teaching. Procedia Engineering, 23, 339-344. https://doi.org/10.1016/j.proeng.2011.11.2512

Zhang, C., \& Chen, X. (2012). Use of Multimedia in Gross Infective Pathogen Experimental Teaching. Procedia Engineering, 37, 64-67. https://doi.org/10.1016/j.proeng.2012.04.203

\section{Copyrights}

Copyright for this article is retained by the author(s), with first publication rights granted to the journal.

This is an open-access article distributed under the terms and conditions of the Creative Commons Attribution license (http://creativecommons.org/licenses/by/4.0/). 